\title{
Bonding in Pursuit of Policy Goals: How MPs Choose Political Parties in the Legislative State of Nature
}

How do MPs in nascent legislatures choose a political party? We argue that MPs self-select into groups of like-minded colleagues to achieve favored policy outputs. MPs identify colleagues with similar preferences based on observed behavior and informative signals such as socioeconomic status, cultural background, and previous political experience. We test this explanation in the first democratically elected German parliament, the Frankfurt Assembly of 1848, that developed a differentiated party system in the absence of electoral and career incentives. Our statistical analysis shows that MPs were significantly more likely to join parties that were similar to them with regard to ideology, age, regional provenance, confession, noble status, and previous parliamentary experience. Qualitative evidence suggests that major changes in the party system were driven by disputes over policy. Our findings are particularly important for countries with more turbulent paths towards parliamentarization than those witnessed by archetypical cases like Britain or the United States.

Political parties were born in 19th-century legislatures (Duverger 1972; Katz and Mair 1995; Krouwel 2006; Scarrow 2006). Today, they play a dominant role in electoral competition and the internal workings of parliament in virtually all democracies. A sizeable body of research has relied on re-election, career, and policy goals to explain why rational MPs give up individual freedom by joining parties (e.g., Aldrich 1995; Cox and McCubbins 1993; for a survey, see Saalfeld and Strøm 2014).

By contrast, we know little about the related question of how MPs in early legislatures decided which party to join. This question is only addressed in the literature on party switching (e.g., Desposato 2006; Heller and Mershon 2009; Mershon and Shvetsova 2013; for a review, see Mershon 2014). However, the 
strategic situation of party switchers in established democracies differs markedly from the initial sorting process of MPs during party formation so that findings from this literature are not necessarily applicable.

This article develops and tests a theory of party choice in nascent, 19th-century legislatures based on MPs' policy objectives. Building on Cox's (2006) concept of a "legislative state of nature," we argue that individual legislators join groups of like-minded colleagues to increase their chances of implementing common substantive goals in parliament and thus sort into parties based on their policy preferences. MPs infer the policy positions of fellow legislators from observable parliamentary behavior and from characteristics that signal policy preferences, such as cultural background, socioeconomic status, and previous political experience. Our core hypothesis holds that MPs join the party whose membership is the most similar to them on these accounts.

We study party formation in the first democratically elected pan-German parliament, the "Frankfurt Assembly" (FA) during the revolution of $1848 / 49$, in order to test this claim empirically. ${ }^{1}$ Within a few months, members of the assembly developed an elaborate system of parliamentary parties. This rapid development is surprising because MPs were elected based on their standing as local dignitaries without established political parties, and most of them were political newcomers without predictable political career prospects. Using quantitative and qualitative methods, we demonstrate that the decisions of MPs to associate with specific parties can indeed be explained by the desire to bond with like-minded colleagues in pursuit of policy goals. Our quantitative analysis of party choice finds strong support for the relevance of ideological proximity and other informative cues such as similarity with regard to age, regional provenance, religious confession, noble status, and previous parliamentary experience. Furthermore, qualitative evidence on major party splits and mergers identifies policy goals as decisive factor for broader changes in the party system.

The article contributes to the general literature on party formation in various ways. First, it provides one of the first empirical studies of how MPs in nascent parliaments choose between alternative parties. Second, by analyzing a case outside the Anglo-Saxon world, we broaden the scope of research on party formation in 19th-century Europe where many cases do not share 
the rather linear and uninterrupted process of party development (Scarrow 2006; Ziblatt 2017, Chap. 2). Third, we show that electoral incentives and career advancement that figure prominently in previous research on why MPs join parties are not necessary for initial party formation-policy incentives alone can be sufficient to explain the sorting process.

\section{How Do MPs Decide to Join a Party and Which Party Do They Choose?}

Existing research mostly addresses the question of why MPs create political parties at all. According to this literature, the emergence of parties in a hypothetical "legislative state of nature" (Cox 2006) can be explained as a strategy of rational MPs; however, studies differ with regard to the goals that MPs are assumed to pursue. One strand argues that policy-seeking MPs join parties to overcome social choice problems (Aldrich 1995; Schwartz 2018) and common pool dilemmas in the use of plenary time that threaten to produce legislative gridlock (Cox 2006). In this view, parties are stable coalitions of MPs formed within parliament that increase the chances that MPs obtain favored policy decisions. A second type of argument, often used alongside policy seeking, treats parties as vehicles for individual career ambitions because they control access to leadership positions within parliament and the executive branch (Carroll, Cox, and Pachón 2006; Cox 1987; Cox and McCubbins 2005; Sieberer 2013). A third type of explanation conceptualizes parties as instrumental for MPs' (re)election goals. In this view, parties are decision heuristics for voters that enable MPs to establish long-standing links with the electorate (Aldrich 1995; Cox and McCubbins 1993). Many implications of these arguments find empirical support in the process of party emergence and development in (mostly) Anglo-Saxon democracies (Aldrich 1995; Bowler 2000; Carroll, Cox, and Pachón 2006; Cox 1987; Cox and McCubbins 1993, 2005; Godbout and Høyland 2015).

We know much less about the question of how MPs in nascent parliaments sort into parties, that is, which party an individual MP chooses. The question of party choice has only been studied with regard to party switching in modern parliaments (Desposato 2006; Desposato and Scheiner 2008; Heller and Mershon 2009, 2008; Laver and Benoit 2003; Mershon and Shvetsova 2013; Thames 2007). According to these studies, 
legislators switch to parties that offer better career opportunities (e.g., to government rather than opposition parties) (Desposato 2006; Heller and Mershon 2008) and parties with better access to offices within the legislature (McElroy 2009) and better electoral prospects (Desposato 2006; Desposato and Scheiner 2008; Laver and Benoit 2003).

However, these findings cannot easily be transferred to initial party choice in nascent parliaments. Almost all modern MPs self-select into parties well before running for legislative office and usually stay true to this party. Those legislators who do switch parties later in their career are most likely an unrepresentative sample, for example, disappointed career politicians or MPs revolting against party discipline. Thus, findings on their behavior may not apply to the larger universe of MPs. Furthermore, party switchers today operate in a context with established offices, hierarchies, and parties as electoral organizations and thus can anticipate how party switching should affect their office and re-election goals, neither of which is necessarily true in nascent parliaments.

Thus, we currently lack a theory of how legislators sort into parties in settings that resemble a "legislative state of nature." In the next section, we develop a theory of partisan sorting in nascent parliaments based on MPs' policy goals and discuss alternative explanations based on career and re-election goals.

\section{A Policy-Based Theory of Partisan Sorting}

Our theory of party choice assumes that MPs seek to influence legislative outputs, that is, they pursue some substantive agenda beyond personal rent seeking. This assumption is met even in minimally organized parliaments - in fact, the bottleneck problem that characterizes Cox's (2006) "legislative state of nature" arises because MPs pursue different policy goals and introduce legislative motions to these ends. In contrast to alternative explanations based on office seeking or vote seeking that we discuss below, our theory does not presuppose the existence of additional institutions beyond the plenary of the legislature.

Our core claim holds that MPs self-select into parties whose members are as similar as possible to themselves with regard to policy preferences because this enhances their impact on collective policy decisions. In collective choice situations, MPs can increase their voting weight by joining coalitions with others. The 
more similar the preferences of her or his partners are, the closer the joint position should be to an MP's ideal point. Thus, all else being equal, joining such a coalition increases the likelihood of achieving preferred outputs. In repeated interactions, longstanding voting alliances are more profitable than ad hoc coalitions because they reduce transaction costs and facilitate credible commitment (Aldrich 1995, Chap. 2; Schwartz 2018, Chap. 8). Forming stable coalitions across multiple votes is less difficult than often assumed because legislative decisions tend to align on a relatively low number of dimensions that create a "basic space" of legislative conflict (Armstrong et al. 2014; Hinich and Munger 1996; Poole 2005). For the Frankfurt Assembly that we study below, previous research has established a two-dimensional basic space (Herrmann and Sieberer 2018).

The tendency to choose a party of like-minded MPs should be self-reinforcing as parties should prefer a membership with rather homogenous policy preferences as well. For one, party leaders internalize and work for the collective interests of the party in exchange for being delegated increased decision-making authority by party members (Cox and McCubbins 1993, 2005). These collective interests include pursuing a consistent policy program (either as an end in itself or to uphold a distinguishable party brand for electoral purposes), which will be easier if policy preferences within the group are well aligned. Second, if party members with similar policy preferences delegate more extensive powers to leaders (e.g., Aldrich and Rohde 2000), leaders interested in their personal power have additional reasons to prefer a cohesive party membership. Thus, both policy-seeking MPs and party leaders prefer parliamentary parties that consist of MPs with similar policy preferences. Only new lines of conflict can upset this equilibrium and induce dynamics into the party system (Riker 1982, Chap. 8).

In our theory, the fundamental challenge for MPs is identifying like-minded colleagues. Legislators can gain the necessary information in two ways. First, they can observe how other MPs act in parliament, for example, in voting and speaking on the floor. If the central lines of conflict are addressed in the legislature, as is likely to be the case given the predominance of a basic space, MPs can directly infer policy positions of other colleagues and identify likely allies.

If such direct information is not (yet) available, for example, in the very first sessions of a new assembly, MPs can rely on 
personal characteristics of their fellow legislators as informative cues to their policy preferences. For example, MPs with similar socioeconomic status (e.g., wealth, profession, noble status) should have similar economic interests and thus policy preferences. Likewise, cultural background (e.g., language, religious denomination, regional provenance) can serve as indication of substantive preferences as may previous political activities outside parliament.

Our theoretical argument yields two testable hypotheses on the factors that drive MPs' choice of a party:

H1: MPs will join the party whose members are the most similar to them with regard to observed or signaled policy preferences.

H2: Due to its higher informational content, MPs' plenary behavior is the most powerful predictor of party choice compared to the other types of signals.

As argued above, this initial sorting should be stable. However, our argument identifies two conditions that should lead to party switching at later stages:

H3: MPs reassess their initial choice if they gain additional information on the policy positions of their colleagues and, if possible, switch to a party that is even more in line with their own position on the relevant conflict dimension.

H4: MPs reassess their initial choice if a new conflict dimension becomes dominant and join the party that is closest to their own position on this dimension.

Before turning to the empirical analysis, we briefly discuss two alternative (but not necessarily competing) explanations for party choice, which we also address empirically in the penultimate section. First, office-motivated MPs could create or join a specific party to get access to leadership positions within parliament or to other offices selected by parliament (Carroll, Cox, and Pachón 2006; Cox 2006; McElroy 2009; Sieberer 2013). While parties and legislative offices coevolved over time (Cox 2006), the case of nascent legislatures allows us to distinguish empirically between an office-seeking and a policy-seeking explanation of party choice because the former requires the existence of leadership offices and predictable paths of acquiring them with the help of parties.

Second, the decision to join a party may be driven by electoral motivations rather than policy seeking. Electoral motivations are fundamental for contemporary party switchers (Desposato 2006; 
Desposato and Scheiner 2008; Laver and Benoit 2003). This explanation presupposes established links between parties and voters, which is highly questionable for 19th-century parliaments, where MPs won elections based on their personal standing as local notables without any role for extraparliamentary parties (on Austria: Berchtold 1986; on France: Duverger 1972; on the FA: Kramer 1968, 74; Langewiesche 1978, 331-32; on Italy: Scarrow 2006).

\section{Historical Background: Parties in the Frankfurt Assembly of 1848}

This section provides crucial background information on our empirical case. The Frankfurt Assembly, which met from May 18, 1848 until May 30, 1849, was the first democratically elected pan-German parliament. ${ }^{2}$ Following the revolutionary uprising of 1848, more than 650 deputies, elected under universal male suffrage in the 38 German states of the time, convened for the purpose of drafting a constitution for a unified German state. The relative power of the FA vis-à-vis the old elites in the various German states was unsettled and varied over time as reformist and restorative forces struggled over predominance (Sieberer and Herrmann 2017; Weyland 2016).

The assembly was very active during its one year of existence. It installed an interim central government called "Provisional Central Power (PCP)" (Provisorische Zentralgewalt) consisting of an elected but nonresponsible Vicar of the Empire and a cabinet that depended on the confidence of the assembly. It also adopted various federal laws, among others a charter of Civil Rights. As the apparent climax, the FA passed a constitution for the German Empire (Reichsverfassung) on March 27, 1849 and elected the Prussian King as emperor. However, by that time, restorative forces had pushed back the liberal revolution, and the Prussian King refused the imperial crown. After this failure, most conservative and liberal MPs left the assembly whereas a smaller group of left MPs continued to meet in Stuttgart before the assembly was dissolved by police in June 1849.

Members of the FA developed parliamentary party groups within a very short period of time even though political parties were legally prohibited and did not exist in Germany prior to $1848 .^{3}$ Nomination and election for the FA were based on candidates' personal reputation and recommendations by local dignitaries, not on specific party programs (Kramer 1968, 74; Langewiesche 1978, 331-32). 
Nevertheless, MPs started to sort into groups as soon as the FA started operating. The Saxon MP Karl Biedermann stated that "by the beginning of June, the process of party formation was so far advanced that one can speak of finished, constituted and organized parties" (Biedermann 1849, 11, translation by the authors; see also Eyck 1968, 133-50; Kramer 1968, 74-80). Originally, four ideologically defined groups can be distinguished that are referred to in the literature as left, center-left, centerright, and right. After further splits, the party system reached its highest degree of differentiation in the fall of 1848 with a total of eight party groups, each named after the Frankfurt inn in which it held its meetings. Starting in December 1848, the party system restructured when a second conflict dimension (the question of including or excluding Austria) took center stage (Kramer 1968, 141-46; Ziebura 1963, 215-18). We discuss the different party splits and mergers in more detail in the empirical section.

Programmatically, scholars arrange the eight parties on a left-right dimension according to their position on the prevalent conflict over popular sovereignty in the constitution (Best 1990, 325-27; Boldt 1971, 53-68; Eyck 1968, 133-50; Herrmann and Sieberer 2018). On the left, Donnersberg and Deutscher Hof advocated a democratic republic based on popular sovereignty. The left-centrist Württemberger Hof supported a parliamentary monarchy. During the summer of 1848 , its left and right wings split off as Westendhall and Augsburger Hof, respectively. The center-right was dominated by the liberal Casino, the largest and internally most heterogeneous party, which supported a constitutional monarchy with a strong federal executive. Its left wing split off as Landsberg in August 1848. Finally, the conservative right was concentrated in Café Milani, a group that supported the old order with strong monarchies and a weak central state. In addition to these party groups, a large number of MPs chose to remain unaffiliated.

Already in the summer of 1848, party groups clearly delineated themselves from others, institutionalized a formal membership, and passed programmatic documents on their constitutional goals and statutes regulating internal decision making (Boldt 1971, 163-92; Kramer 1968, 79-88; Langewiesche 1978, 333-35; Ziebura 1963, 211-12). Among other things, party rules required MPs not to vote against the majority of their group (abstentions were tolerated) if a matter was declared a party vote (Parteifrage) ${ }^{4}$ and not to introduce motions, amendments, and interpellations 
without clearance by the party caucus. Nonetheless, dissenting votes and motions that were not cleared by the parties were frequently observed and often went unsanctioned (Kramer 1968, 84, 22-224; Ziebura 1963, 212-14). Moreover, the parties did not install strong intraparty leadership positions but made all relevant decisions by majority vote in the caucus (Botzenhart 1977, 430; Kramer 1968, 212-13). Thus, the organizational rules helped increase the policy impact of the party within the assembly but did not create party offices that would trigger MPs to join a party for career reasons.

Historical research suggests that many of the factors identified by our theory influenced the decisions of MPs to join specific parties. There is general consensus that MPs sorted into parties based on ideological similarity (Best 1990, 353; Kramer 1968, 115; Mattheisen 1981; Ziebura 1963, 210). By contrast, scholars disagree on the relevance of additional characteristics. While Mattheisen (1981) and Ziebura (1963) claim that ideology was the only relevant factor, Best argues that "political-social affiliations from the time prior to taking up the parliamentary mandate" also played a role (1990, 353, translation by the authors). Such factors include the regional provenance of MPs (Best 1990, Chap. 8; Eyck 1968, 140-41, 198-202; Kramer 1968, 75), their professional background (Best 1990, Chap. 8; Kramer 1968, 75), their noble status (Best 1990, Chap. 8; Kramer 1968, 75), confessional divisions (Eyck 1968, 141-48; Kramer 1968, 218), and personal acquaintance (Kramer 1968, 75). However, the relevance of these factors is often claimed based on rather unclear evidence, and no study provides a systematic joint assessment of their effects.

\section{Research Design}

Testing our theoretical argument requires information on individual MPs' party affiliations. Like many analyses of historic parliaments, our study faces problems of data availability. While contemporary and historical handbooks record the party affiliation(s) of each MP and thus identify party switchers (Best and Weege 1996; Koch 1989), the historical record does not tell us when exactly individual MPs joined a given party. The only available information with a clear date attached is party membership lists for October 1848 (Best 1990, 326). Thus, we cannot model individual party choice in a dynamic fashion. 
We use a mixed methods analysis to deal with this problem. The quantitative component analyzes the composition of parties on October 1, 1848, the date for which we have precise party membership data. At this point in time, the party system had reached its highest level of differentiation, consisting of eight parties, which makes predicting an MP's choice of party more difficult. Thus, the analysis constitutes a particularly demanding test for our expectations. Afterwards, we qualitatively investigate cases of party splits and mergers that occurred over the entire history of the FA. In contrast to individual party switchers, these events are discussed in historical accounts of the FA, which allows us to assess Hypotheses 3 and 4.

For the quantitative analysis, we conceptualize party membership on October 1, 1848 as an MP's decision in favor of the party he belonged to on that day over all available alternatives, including the option of being unaffiliated. ${ }^{5}$ Given widespread party switching (26\% of all MPs switched at least once) (Best 1990, 330), we can interpret party membership as reflecting an ongoing evaluation of all available options by MPs (McElroy 2009; Mershon and Shvetsova 2013). Statistically, we treat the decision of an MP to be a member of a specific party as a discrete choice problem and model it via the conditional logistic regression model with alternative-specific predictors (McFadden 1974).

According to our theory, MPs chose the party whose members are the most similar to themselves regarding their preferences on the constitution for the future German state. Thus, our explanatory variables measure the similarity between a legislator and the different groups on the four clusters of characteristics that MPs can use to infer preference similarity: cultural background, socioeconomic status, previous political experience, and ideology as observed via previous legislative behavior. We measure the first three clusters of characteristics with variables from a data set on the members of the FA that was collected by Heinrich Best (1990; Best and Weege 1996). ${ }^{6}$ In addition, we use original roll-call data from the very beginning of the FA and estimate MPs' ideological positions in order to capture the information that MPs could obtain about their colleagues' political preferences from observing their behavior in the chamber. Table 1 summarizes the 11 variables we use; the online Supporting Information provides descriptive statistics and further information on the calculation of the similarity measures. 


\section{TABLE 1}

Explanatory Variables and Their Operationalization

\begin{tabular}{|c|c|}
\hline Variable Name & Operationalization \\
\hline \multicolumn{2}{|l|}{$\overline{\text { Cultural Background }}$} \\
\hline Similarity: Age & $\begin{array}{l}\text { (Absolute difference between MP's age and mean age } \\
\text { in each party group/maximum age difference) } \\
(-1) \text { [standardization to range of one and change of } \\
\text { sign to create a similarity instead of a distance } \\
\text { measure] }\end{array}$ \\
\hline Similarity: Confession & $\begin{array}{l}\text { Share of MPs with the same confession as the } \\
\text { analyzed MP in each party group }\end{array}$ \\
\hline Similarity: Region & $\begin{array}{l}\text { Share of MPs elected from the same region as the } \\
\text { analyzed MP in each party group }\end{array}$ \\
\hline \multicolumn{2}{|l|}{ Socioeconomic Status } \\
\hline Similarity: Nobility & $\begin{array}{l}\text { Share of MPs with the same status (nobility or } \\
\text { commoner) as the analyzed MP in each party } \\
\text { group }\end{array}$ \\
\hline Similarity: Profession & $\begin{array}{l}\text { Share of MPs with the same occupation as the } \\
\text { analyzed MP in each party group }\end{array}$ \\
\hline \multicolumn{2}{|l|}{ Political Experience } \\
\hline $\begin{array}{l}\text { Similarity: Parliamentary } \\
\text { mandate before } 1848\end{array}$ & $\begin{array}{l}\text { Share of MPs with the same parliamentary experi- } \\
\text { ence as the analyzed MP in each party group }\end{array}$ \\
\hline $\begin{array}{l}\text { Similarity: Political office } \\
\text { before } 1848\end{array}$ & $\begin{array}{l}\text { Share of MPs with the same office experience as the } \\
\text { analyzed MP in each party group }\end{array}$ \\
\hline Similarity: Vorparlament & $\begin{array}{l}\text { Share of MPs with the same experience in the } \\
\text { Vorparlament as the analyzed MP in each party } \\
\text { group }\end{array}$ \\
\hline Similarity: Political club & $\begin{array}{l}\text { Share of MPs with the same experience as members } \\
\text { of political clubs as the analyzed MP in each party } \\
\text { group }\end{array}$ \\
\hline Similarity: Political sentence & $\begin{array}{l}\text { Share of MPs with the same experience regarding } \\
\text { political sentences as the analyzed MP in each } \\
\text { party group }\end{array}$ \\
\hline \multicolumn{2}{|r|}{ P } \\
\hline Similarity: Ideology & $\begin{array}{l}\text { (Absolute difference between MP's ideological } \\
\text { position and median member of each party) } *(-1) \\
\text { [change of sign to create a similarity measure] }\end{array}$ \\
\hline
\end{tabular}

Note: All variables have a range of one point with higher values indicating higher similarity to a group.

Three variables capture the similarity between MPs and party groups with regard to cultural background: age, confession, and regional provenance. First, MPs of similar age share formative experiences in the turbulent first half of the 19th-century (e.g., the Napoleonic age, the restorative period after 1815 , or the cautious attempts at liberalization in the 1830s), which should affect their constitutional preferences via cohort effects. As empirical 
measure of similarity, we use the absolute difference between an MP's age and the mean age of MPs in each party group. This difference is multiplied by -1 to create a similarity (rather than distance) measure. ${ }^{7}$ Second, historical studies mention confessional bounds as one driver of party formation (Eyck 1968, 141-48; Kramer 1968, 218). We distinguish between Catholic and other (mainly Protestant) MPs and calculate the share of MPs in each party group (excluding the analyzed MP) who belong to the same confession as the analyzed MP (e.g., the share of Catholics for a Catholic MP). Third, we take the region in which an MP was elected as a measure of his cultural background. Even though the FA aimed at creating a German nation-state, regional bonds and differences were strong at the time so that MPs should be more likely to join groups with many compatriots (Best 1990, Chap. 8; Eyck 1968, 140-41; Kramer 1968, 75). We distinguish between the 10 regions used in the Best (1990) data set (see the online Supporting Information) and calculate the share of MPs in each party who were elected from the same region as the analyzed MP.

Similarity in socioeconomic status is measured with two variables. First, we distinguish between members of the nobility and commoners and calculate the share of each party that has the same status as the MP. Members of the nobility had a joint interest in preserving the old order to retain political, social, and economic prerogatives. Furthermore, we consider the profession of MPs before joining the Frankfurt Assembly (measured in 10 categories, see the online Supporting Information) and calculate the share of party members from the same profession as the MP. While the occupational categories are rather broad and internally heterogeneous, they tap into common socioeconomic interests of MPs.

To capture shared political experience, we analyze whether an MP held a political office on the local, regional, or state level before being elected to the FA, whether he held a parliamentary mandate on the state level before 1848, and whether he was a member of the so-called Pre-Parliament (Vorparlament). ${ }^{8}$ We also include two variables on political socialization outside of formal offices because left-leaning members did not have access to such offices prior to 1848 . The first variable indicates whether MPs were members of political clubs that were important proto-political organizations in the absence of political parties (Langewiesche 1978, 328). Second, we identify MPs who were sentenced for political reasons before 1848, which should be a formative experience 
for dissidents. For all variables, we calculate the share of members in each party group who shared the same experience as the analyzed MP.

The fourth factor is an MP's ideological proximity to the different parties as observed from previous actions in the FA. Theoretically, this proximity is the most important determinant of party choice because it provides the most direct information on policy preferences. We infer ideology from roll-call voting as the only available data source. ${ }^{9}$

We extract MPs' positions based on the first 20 recorded votes in the FA, the last of which was taken on August 10, 1848, via Bayesian ideal point estimation (Clinton, Jackman, and Rivers 2004; Jackman 2008). ${ }^{10}$ These votes constitute a single dimension that correctly predicts $90 \%$ of all voting decisions. ${ }^{11}$ Substantively, they include decisions on fundamental issues such as the creation of the Provisionary Central Power, the abolition of the death penalty, and the elimination of the special status of the nobility. As we explain in more detail in the online Supporting Information, all votes refer to the fundamental question of how political (and to some extent also societal and economic) power should be distributed in the new German state between monarchical elites and more liberal or even democratic forces and thus capture the main line of conflict in the FA (Boldt 1971, 63). We rescale ideological positions to range from -0.5 to 0.5 and measure ideological similarity as the absolute distance between an MP's ideology score and the median score of each party group. Again, we multiply this distance by -1 , yielding a variable with a theoretical range from -1 (lowest similarity) to 0 (highest similarity).

Our roll-call-based measure of ideology would be problematic if parties exerted strong pressure on the voting behavior of their members, so that estimated positions were a consequence rather than a cause of party membership. However, several reasons speak against such an endogeneity problem. First, the votes used to measure ideological positions took place before the party system we seek to explain had fully developed because three party groups were founded after August 10, 1848. Second, party switching was very frequent in this early period, indicating that MPs mostly acted based on their own opinions and, if necessary, sought or founded new parties more in line with their ideological positions (Best 1990, 330; Kramer 1968, 74-80). Third, as Figure 1 shows, the estimated positions vary considerably within parties, which is not what we usually see with strong party-line voting. ${ }^{12}$ 
FIGURE 1

Ideological Positions of FA Members Estimated from Roll Calls until August 10, 1848

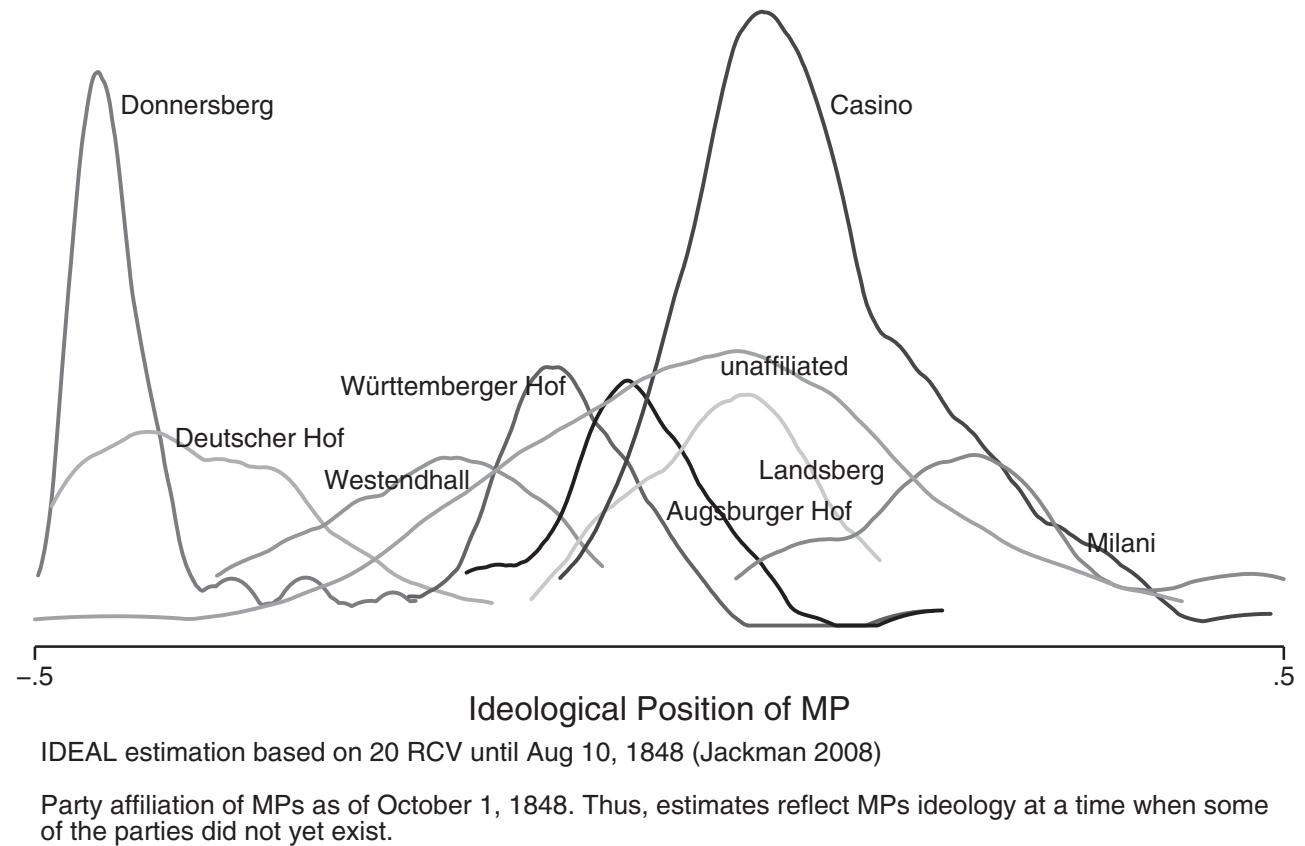

Taken together, the evidence suggests that our measure of ideology is as exogenous to party pressure as a roll-call-based measure can be. ${ }^{13}$

When estimating the effects of ideological similarity, we must account for the fact that MPs' positions themselves are subject to estimation error. Simply using the estimated ideal point to predict party choice would understate the uncertainty about the effect of ideology. We take a multiple imputation approach to allow variability in estimates of MP positions to carry over into the model of party choice (Rubin 1987). ${ }^{14}$ For this purpose, we create 100 data sets and for each randomly draw MPs' positions from the posterior distribution of their estimated ideal points; all other variables remain unchanged across data sets. We then run 100 conditional logit models - one per data set - and combine our inferences (coefficients, standard errors, confidence intervals, LR test statistics) according to Rubin's Rules (Meng and Rubin 1992; Rubin 1987; see the online Supporting Information for further details). By accounting for the uncertainty in estimates of MP position, this procedure yields more conservative inferences about the effects of ideology. 


\section{Empirical Findings}

Quantitative Analysis: Modeling Party Choice in October 1848

On October 1, 1848, the Frankfurt Assembly consisted of 559 MPs in eight party groups. Casino was by far the largest party with 128 members while the sizes of the other parties ranged between 37 and 51 (Table 2). One hundred and twenty-five MPs were unaffiliated. Our analysis sample reduces to 506 members because some MPs had not cast any roll-call votes during the early period that we use to estimate ideological positions. As the distribution of MPs across parties is very similar in the two samples (Duncan Index of Dissimilarity $=0.03$ ), our findings should not be biased by the restricted sample.

We estimate three different model specifications. Model 1 includes all explanatory factors. Model 2 focuses solely on ideological similarity estimated from previous voting behavior as the most direct source of information for an MP seeking like-minded colleagues. Model 3 contains all explanatory variables except ideological similarity. This specification mirrors most directly the information available to MPs at the very start of the assembly when no parliamentary behavior could be observed yet. Furthermore, this model yields better estimates of how the indirect sources of

TABLE 2

Party Membership in the Frankfurt Assembly on October 1, 1848

\begin{tabular}{lccccc}
\hline & \multicolumn{2}{c}{$\begin{array}{c}\text { All MPs in Office } \\
\text { on Oct. 1, } 1848\end{array}$} & & \multicolumn{2}{c}{ Analysis Sample Only } \\
\cline { 2 - 3 } \cline { 6 - 6 } \cline { 5 - 6 } & Number & Share & & Number & Share \\
\hline Donnersberg & 50 & 0.089 & & 42 & 0.083 \\
Deutscher Hof & 51 & 0.091 & & 45 & 0.089 \\
Westendhall & 46 & 0.082 & & 38 & 0.075 \\
Württemberger Hof & 37 & 0.066 & & 35 & 0.069 \\
Augsburger Hof & 38 & 0.068 & & 34 & 0.067 \\
Landsberg & 42 & 0.075 & & 41 & 0.081 \\
Casino & 128 & 0.229 & & 126 & 0.249 \\
Milani & 42 & 0.075 & & 41 & 0.081 \\
Unaffiliated & 125 & 0.224 & & 104 & 0.206 \\
Total & 559 & 1.00 & & 506 & 1.00 \\
\hline
\end{tabular}


information (culture, socioeconomic status, and political experience) affect party choice. If ideology is (partly) caused by these factors, their effect will be (partly) mediated by this variable and thus be underestimated in Model 1.

Figure 2 displays the estimated coefficients for the three specifications of the conditional logit model along with 95\% confidence intervals; the precise estimates are provided in the online Supporting Information. ${ }^{15}$ Our theory expects positive effects throughout because all variables are designed as similarity measures (Hypothesis 1). Furthermore, we expect the effect of ideological similarity to be the strongest because it provides the strongest signal (Hypothesis 2). As all independent variables have a range of one point, we can directly assess their relative explanatory power by comparing coefficients.

The results provide strong support for our theoretical argument that MPs join groups that are more similar to themselves. MPs are more likely to join a party group the closer they are to the party's median member. As expected, the effect of ideological similarity is by far the strongest in the model. Furthermore, this variable is less important for the decision to stay unaffiliated

\section{FIGURE 2}

Conditional Logit Models of MPs' Choice of Party (October 1848)

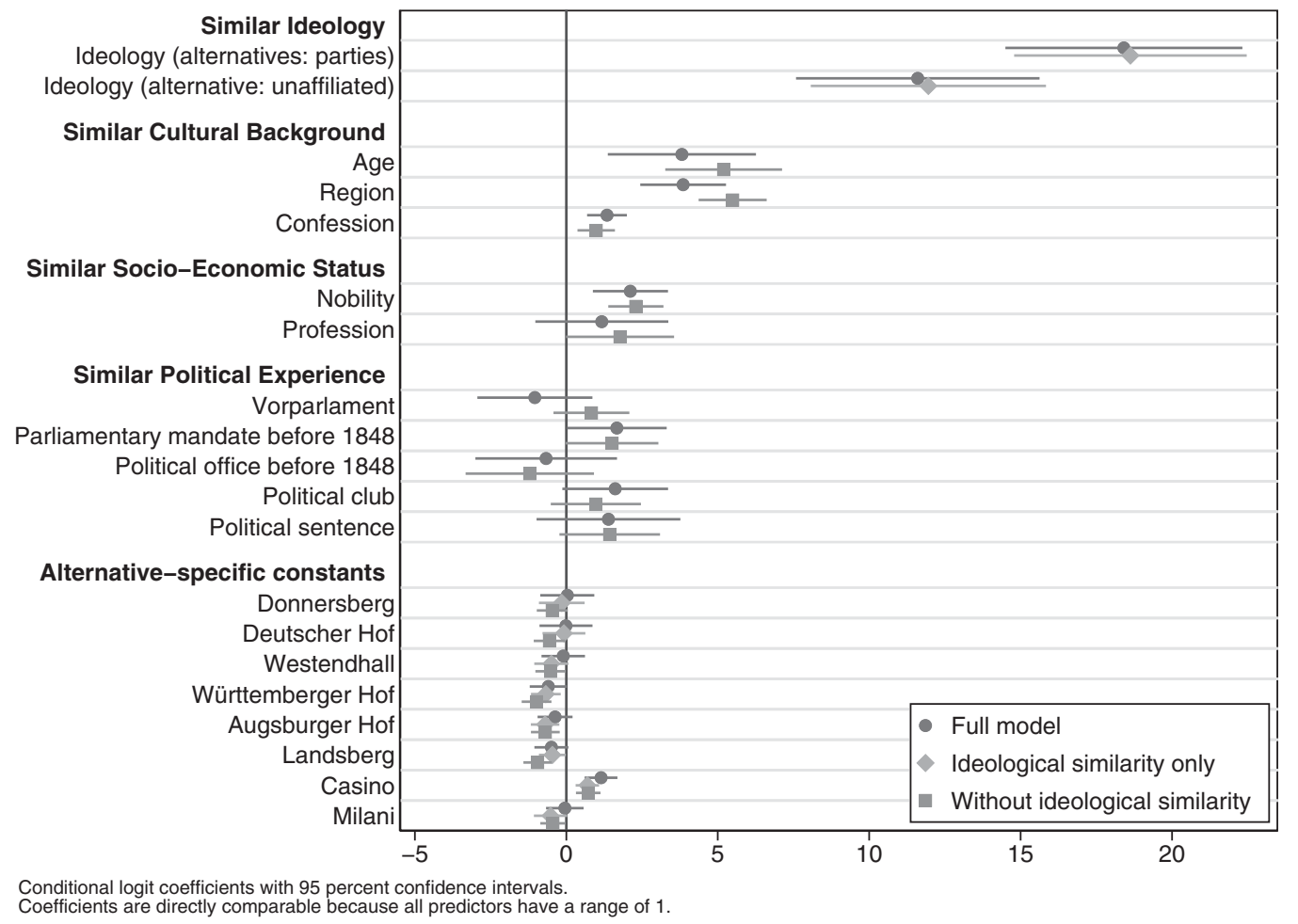


rather than joining one of the eight party groups. As we explain in the online Supporting Information, unaffiliated MPs are not a group with a shared programmatic agenda, hence the ideological make-up of this group should be less important for the choice of staying unaffiliated. To allow for this, we estimated separate coefficients for the choice of staying unaffiliated and the choice of joining one of the eight party groups (Long and Freese 2006, $312-13) .{ }^{16}$ The effects of ideology are virtually identical in the full model and in the model that contains only the ideological similarity variables.

Our findings also support the claim that MPs sort into parties based on cultural and socioeconomic background as informative signals of their colleagues' policy preferences. MPs are significantly more likely to join groups whose average member is of a similar age. Furthermore, they prefer groups that are more similar to them with regard to electoral region, confession, and noble status. Occupational similarity, on the other hand, does not significantly affect party choice, which may be due to the broad categories of this variable. The effects of age and regional similarity are substantively stronger in the specification excluding ideology compared to the full model, suggesting that these factors are systematically related to ideology. The other effects are similar in both specifications.

Against our expectations, similar political experience has little effect on party choice. While most of the coefficients are positive, only similarity with regard to holding a parliamentary mandate before 1848 is statistically significant in the full model. This result may be due to the low informational content of the available data. MPs who held a political office or were members of some political club may differ in their preferences depending on the specifics of the respective office or club. The small and often insignificant alternative-specific intercepts indicate that our explanatory variables capture most of the systematic variation in the data. The only exception is Casino, which is chosen slightly more often than expected given the explanatory variables in the model.

Likelihood ratio tests show that the full model fits the data significantly better $(p<.05)$ than either specification (2) or (3). Thus, combining measures of ideological similarity with similarity measures based on other MP characteristics yields a better explanation of party choice than a sole reliance on either group of 
predictors. Background characteristics have independent effects that are not fully mediated by ideology. ${ }^{17}$

To assess substantive effect sizes, we translate the coefficients from the full model into average choice probabilities (Hanmer and Kalkan 2013). Figure 3 shows how the probability that an MP joins a specific party changes when the party gets more similar to the MP with regard to a specific attribute (e.g., ideology), while holding all other predictors constant at their observed values, including the similarity to all other parties with regard to the attribute under consideration (e.g., ideological similarity to other parties). The gray lines show the average of these probabilities across MPs from each group (the eight parties and the group of unaffiliated MPs); the black line indicates the overall effect of averaging across the probabilities for the nine groups.

FIGURE 3

Substantive Effect Sizes in the Full Model

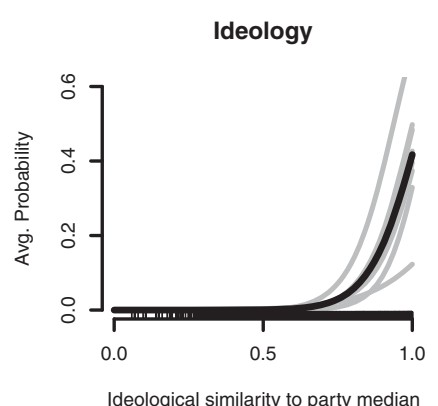

Age

Region
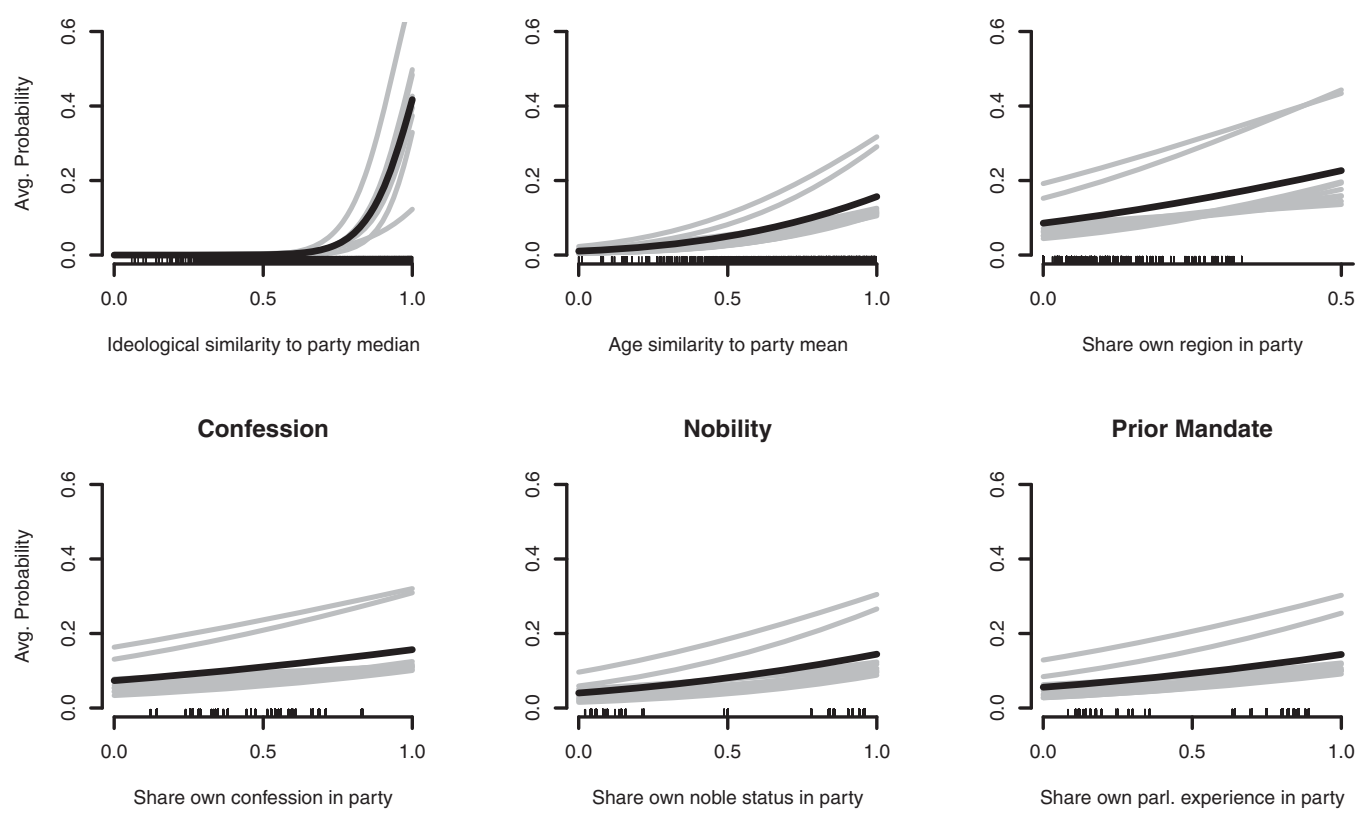

Note: Average predicted probabilities of joining a party (or staying unaffiliated) as a function of a party's similarity to an MP. Gray lines indicate the probability of joining a specific party (or staying unaffiliated). Each black line represents the average of these probabilities across all alternatives. Each choice probability (gray line) is computed by changing the similarity of a club to an MP while holding all other variables at their observed values. Probabilities are then averaged across all MPs to give the above predictions. Ticks underneath each graph indicate the observed distribution of the predictor. For regional similarity (upper-right panel), the x-axis does not extend beyond 0.5 due to the lack of observed values. 
The six variables that are statistically significant in the full model all have substantively important effects. For the strongest variable, ideology, the probability of joining a party increases from 0 to $40 \%$, on average (and even beyond this value for some parties), when a party gets ideologically more similar to an MP. The effect is strongest for the probability of joining Casino, which is indicated by the gray line with the steepest slope in the upper-left plot. Conversely, the effect of ideology is weakest for the choice to remain unaffiliated, as indicated by the gray line with the smallest slope. Effect sizes for the other variables range from 10 to 20 percentage points, on average, for a minimum-to-maximum change in similarity to a given party. The two alternatives that stand out in each plot are Casino (first line from the top) and staying unaffiliated (second line from the top). Overall, the effects of similarity are substantial, especially if we keep in mind that we predict the choice of one out of nine alternatives and that effects may add up across different dimensions of similarity.

\section{Qualitative Analysis: How Policy Seeking Drives Party Splits and Mergers}

Due to data availability, the quantitative analysis of individual MPs' party choices is confined to one point in time. However, we can also test our theory by tracing temporal dynamics of the party system and assessing qualitatively whether party splits and mergers can be explained by policy-based sorting. We first look at the differentiation of the party system leading up to the situation on October 1, 1848 and subsequently its reconfiguration starting in December 1848. These changes provides evidence on Hypotheses 3 and 4, according to which changes of the party system are driven by newly available information on MPs' policy positions or by changes in the underlying conflict dimensions.

By June 1848, that is, within about six weeks, MPs had created four large parties: Deutscher Hof on the left, Württemberger Hof on the center-left, Casino on the center-right, and Café Milani on the right. During the summer of 1848 , splits in all parties except Café Milani produced the system of eight parties that we analyzed above (Botzenhart 1977, 415-29; Kramer 1968, 92-95; Langewiesche 1978).

Historical research attributes at least three of four splits to disagreement on fundamental constitutional policy questions. On 
the left, the radical wing of Deutscher Hof formed Donnersberg at the end of June 1848 after a dispute over the design of the "Provisional Central Power" (PCP) (Botzenhart 1977, 167; Kramer 1968, 101-02). On a deeper level, the radical democrats of Donnersberg did not want to rule out the option of a second revolution in order to implement their political goals whereas Deutscher Hof did (Botzenhart 1977, 427). On the center-left, two groups split off Württemberger Hof. In August, a small left wing formed Westendhall to promote more democratic elements such as universal, equal, and direct suffrage (Botzenhart 1977, 424). In September 1848, the remaining Württemberger Hof split following fundamental disagreement on the relationship between the FA and the existing German states. This conflict crystallized on the question of whether the FA should accept an armistice that the Prussian government had negotiated with Denmark to end the military conflict over the duchies Schleswig and Holstein, even though the armistice did not comply with conditions set by the FA. The cabinet, which drew its parliamentary support from a coalition of Württemberger Hof, Landsberg, and Casino, grumblingly accepted the armistice. However, a legislative majority including the left wing of Württemberger Hof rejected the agreement, leading to the resignation of the cabinet. In response, the right wing of the party formed Augsburger Hof and continued to support the newly installed center-right cabinet whereas the remains of Württemberger Hof went into opposition (Botzenhart 1977, 184-87; Kramer 1968, 92-98). The fourth major split occurred in August 1848 when the left wing of Casino formed Landsberg. The underlying reasons are disputed. Kramer (1968, 115-16) emphasizes disagreement over organizational questions within the party, whereas Botzenhart $(1977,423)$ points to policy disagreements claiming that Landsberg took a more democratic (left) position on the power of the FA vis-à-vis the German states and the form of the future government.

From December 1848 onwards, the party system transformed considerably in response to changes in the conflict dimensions in the assembly. In addition to the fundamental dispute over popular sovereignty (the left-right dimension), a territorial dimension emerged on the question of whether Austria should be included in the new German nation-state. While the left mostly supported such a Greater German solution, the other parties were split on the issue. In reaction, supporters of the inclusion of Austria (a majority of Café Milani and a small wing 
of Casino) founded Pariser Hof whereas the minority of Café Milani that supported a Lesser German solution under Prussian dominance joined Casino (Kramer 1968, 147-48). A minority within Westendhall that opposed the inclusion of Austria split off as Neuwestendhall in January 1849 (Kramer 1968, 144-46). During the decisive phase of the constitutional negotiations in early 1849 , like-minded parties increasingly joined forces in larger blocks. On the left, Deutscher Hof, Donnersberg, and the remains of Westendhall and Württemberger Hof cooperated more closely as Vereinigte Linke (United Left) (Kramer 1968, 108-10; Langewiesche 1978). On the center-right, the Lesser German parties Casino, Landsberg, Augsburger Hof, and Neuwestendhall created a joint group called Weidenbusch that advocated a monarchical system without Austria (Kramer 1968, 147-49). During the final months of the FA in 1849, the three larger groupings (Vereinigte Linke, Weidenbusch, and Pariser Hof) were the main factions in parliamentary business whereas the old parties either disappeared altogether (esp. Württemberger Hof) or became wings of the larger groupings (Botzenhart 1977, 428-29; Kramer 1968, 147-49).

The qualitative evidence on the dynamics of the party system supports our theoretical argument that members of the FA sorted into parties based on policy preferences. The splits in 1848 indicate that the differentiation of the party system was driven by policy differences on the dominant conflict dimension and support Hypothesis 3 on the role of new information. After a rough initial sorting into four large ideological groupings, ongoing debates showed MPs how their own positions differed from those of their colleagues. Based on this new information, subgroups with divergent policy preferences formed new parties. These splits occurred within the large ideological groupings (Langewiesche 1978, 338), which suggests that MPs already found a good (even though in some cases not perfect) match in the initial sorting process based on the scarce information they had available during the first few weeks in office. The reconfiguration of the party system in late 1848/early 1849 was driven by divergent substantive preferences for the new territorial dimension in line with Hypothesis 4. As the territorial conflict became prevalent, many MPs sought and found parties that were more aligned with their own preferences on this issue and thus switched parties. These switches also crossed established borders of previous ideological camps (e.g., members of the right-wing Café Milani switching to 
the center-right Casino), which indicates that new conflict dimensions can lead to more fundamental transformations of the party system than a mere gain in information. In our case, this new dimension was inherent to the task of the FA as the territorial question had to be decided at some point. In other contexts, new dimensions may be introduced strategically by actors trying to split the current majority (Riker 1982, Chap. 9; 1986; Weingast 1998). Finally, the finding that ideologically close parties coordinated their behavior to increase their influence on substantive decisions also demonstrates the central role of policy seeking.

\section{Alternative Explanations:}

Vote and Office Rather Than Policy Motivations?

Our analysis showed that party formation in the Frankfurt Assembly is consistent with self-selection of MPs into groups of like-minded colleagues based on joint policy goals. Here, we briefly assess the fit of the two alternative explanations mentioned above. First, the empirical evidence rejects the argument that MPs chose parties for electoral reasons. Parties played no role at all in the elections of 1848; instead, MPs were elected based on their personal reputation in the districts (Botzenhart 1977, 158-60; Kramer 1968, 74; Langewiesche 1978, 331-32). Most deputies were political novices who did not plan a political career, and many left during the course of the FA (Best 1990). ${ }^{18}$ The party groups discussed above developed within the assembly and mostly confined their activities to parliamentary business (Kramer 1968, 109-10; Langewiesche 1978). In parallel, left-leaning political associations (Vereine) on the societal level founded a rudimentary extraparliamentary party called Zentralmärzverein in November 1848 with the aim of promoting their political objectives in the broader public (Langewiesche 1978). The parliamentary parties of the left (Donnersberg, Deutscher Hof, and the left wing of Westendhall) joined the Zentralmärzverein in late November, which led to more cooperation within the assembly as well (Kramer 1968, 108-10). Among liberals and conservatives, no such extraparliamentary organization developed due to a general skepticism towards linking the societal and parliamentary arena (Langewiesche 1978). We can only speculate whether the Zentralmärzverein would have become the seed of an electoral party if democratic elections had been conducted after 1849. For 
our argument, however, the key point is that parliamentary parties were founded well before any extraparliamentary organization existed and that there is no indication that original party choice was based on MPs' electoral motivations.

Second, MPs could join parties to further their individual career ambitions within and beyond parliament. This argument cannot explain initial party formation in 1848 either, because the FA originally lacked powerful internal offices that career-oriented MPs would aim for. The only visible leadership offices, the president of the Assembly and his deputies, were formally charged with determining the agenda ( $\$ 34$ of the Standing Orders). However, in practice they needed the support of a plenary majority so that the party groups themselves became the relevant agenda-setting actors (Kramer 1968, 194, 200-02). The first president, Heinrich von Gagern, even formally remained unaffiliated (even though he shared the ideological position of Casino) because he deemed the office incompatible with overt partisanship (Botzenhart 1977, 422). Parties took internal decisions by majority vote in the caucus and only elected weak leaders for four-week periods (Botzenhart 1977, 430; Kramer 1968, 212-13). Outside of parliament, the FA installed the cabinet of the PCP whose members were mostly drawn from the FA. From September 1848 onwards (i.e., several months after initial party formation), the cabinet functioned according to the logic of parliamentary government (Botzenhart 1977, 163-92; Sieberer and Herrmann 2017). Several prominent members of the FA served as ministers, suggesting that these offices were considered attractive. However, several cabinet reshuffles also indicate that ministers were not able to dominate substantive decisions but served at the (often volatile) will of their parties (Botzenhart 1977, 183-92). Furthermore, there is little evidence that MPs joined or switched parties in order to attain office. One exception may be the creation of Augsburger Hof as this party was founded by a group of Württemberger Hof MPs (including members of the cabinet) who continued to support the cabinet. However, as discussed above, the conflict leading to the split was based on the fundamental policy question of the relationship between the FA and the subnational states. As the defecting group was much larger than the few ministers, it is plausible to assume that many supported the new party for policy reasons, not personal office seeking. Overall, career incentives may have become more relevant over the duration 
of the FA, but the available evidence suggests that policy seeking was the dominant motivation underlying MPs' sorting into parties.

\section{Discussion and Conclusion}

Understanding the formation of political parties is crucial for understanding parliaments and political competition in modern democracies. Most existing research explains party emergence as a gradual process driven by the interaction between career-oriented legislators and their electoral and parliamentary environment. We argue that the initial steps of party formation within parliament can also occur solely based on MPs' policy goals without electoral and career incentives. Legislators realize that they are more likely to influence parliamentary decisions by joining forces with like-minded colleagues. MPs infer the preferences of fellow legislators from observable behavior (especially parliamentary voting), cultural and socioeconomic background, and previous experiences, and subsequently join the party whose members resemble them the most. While previous accounts mainly explain why parties emerge in general, our argument also predicts which parties individual MPs will join. We tested our theoretical claim on a case in which parties developed quickly in the absence of re-election and career incentives: the first democratically elected pan-German parliament in 1848. Our discrete choice analysis of MPs' decisions to join one of eight party groups or remain unaffiliated provided strong support for self-selection of MPs into groups of like-minded colleagues. Furthermore, a qualitative assessment of party splits and mergers also attests to the central importance of policy motivations. Electoral and career concerns as the main alternative explanations were (at least based on available historical information) irrelevant for original party formation but, as we discuss below, might have become more important once parties had been created.

What can we learn from the Frankfurt Assembly about party formation more generally? While the FA looks extraordinary on first sight - an ultimately unsuccessful constituent assembly that only lasted for about a year - it is not that special on closer inspection. Though formally a constituent assembly only, it quickly got involved in everyday politics. The assembly installed a provisionary national executive consisting mostly of members of the FA and passed various laws on issues such as tariffs and 
civil rights (Eyck 1968, Chap. 5). Its internal functioning showed patterns typical for parliamentary systems of government such as high party unity, stable legislative coalitions, and higher legislative success of cabinet parties (Sieberer and Herrmann 2017). The FA's fate was ultimately determined by external factors, in particular a shift in power from revolutionary to reactionary forces (Weyland 2016). However, it did not fail because of internal defects or its emerging party system. The parties formed in the FA (with the exception of the Socialist movement that did not yet exist) even foreshadowed basic structures of the party system that emerged in the German Empire of 1871 and continued at least into the Weimar Republic after World War I (Langewiesche 1978). The party-formation process in the FA thus was not a singular and isolated episode but the starting point for the long-term development of the German party system. Although this process looks winding compared to the developments in Britain and its former colonies, such nonlinear paths were common in continental European countries such as France, Italy, and Spain (Ziblatt 2017). We therefore believe that the FA's experience holds some general lessons for the study of party formation.

First, we submit that the desire to affect policy decisions and to overcome collective action problems can be sufficient for MPs to give up individual freedom of action in favor of joining party groups. However, our emphasis on policy seeking should not be read as an argument against existing office- and voteseeking explanations of party development in the long run. What we show is that electoral and career considerations, which figure prominently in previous work (e.g., Aldrich 1995; Cox 1987; Cox and McCubbins 1993), are not necessary for parliamentary parties to form. This helps explain initial stages of party formation that often occurred inside legislatures with little linkage to the electoral arena (Duverger 1972; Katz and Mair 1995) and arguably also turbulent patterns of party switching in new democracies with highly volatile electorates, for example, in Central and Eastern Europe in the early 1990s (Willumsen 2017, Chap. 5).

Theoretical work and the historical experience of (mostly) Anglo-Saxon countries suggest that vote seeking and office seeking are important drivers of party development in the long run. Political parties, legislative organization, and the parliamentarization of executive offices tend to coevolve over time (Carroll, Cox, and Pachón 2006; Cox 1987, 2006). Our qualitative analysis detected some initial movements in this direction over the 
course of the FA. Societal groups on the left built a rudimentary extraparliamentary party structure and tried to link it to ideologically close parties within the assembly, and members of the assembly occupied newly established cabinet offices. Given the failure of the FA in 1849, it remains an open question whether the policy-based parties that emerged within the assembly would have developed into what we now consider modern political parties: multipurpose organizations that serve their members' policy, office, and vote goals.

The second distinct result of our study is that functioning parliamentary parties can emerge within a few months whereas previous accounts focused on gradual processes over years or even decades (Aldrich 1995; Eggers and Spirling 2014, 2016; Godbout and Høyland 2015). This finding is relevant because the continuous and uninterrupted processes of democratization documented for Anglo-Saxon countries are rather exceptional. In 19th-century continental Europe, a conflict-ridden sequence of struggles between democratic and restorative forces was much more common, and the same is true for most present instances of democratization (Capoccia and Ziblatt 2010; 2017). While parliaments play a crucial role in such struggles, their ability to confront old elites in executive positions of power is often disputed due to the massive coordination problems faced by large assemblies that consist of unexperienced members with little information and few preexisting bonds. Our findings show that, even in such apparent turmoil, joint policy goals and social attraction can quickly induce some stability and thus enable parliaments to take decisive action.

Ulrich Sieberer <Ulrich.Sieberer@uni-bamberg.de> is Professor of Political Science at the University of Bamberg, Department of Political Science, Feldkirchenstrasse 21, D-96045 Bamberg, Germany. Michael Herrmann <Michael.Herrmann@ uni-konstanz.de> is Senior Lecturer at the University of Konstanz, Department of Politics and Public Administration, Box 92, D-78457 Konstanz, Germany. 


\section{NOTES}

An earlier version of the article was presented at the General Conference of the ECPR Standing Group on Parliaments in Munich, Germany, in June 2016. We thank Simon Richter and Christian Spinner for excellent research assistance and Heinrich Best (University of Jena) for allowing us to use his data on members of the Frankfurt Assembly. We also thank three anonymous reviewers and Christopher Kam for their excellent comments and suggestions. The research for this article was supported by the Zukunftskolleg at the University of Konstanz with funds from the Excellence Initiative of the German Federal and State governments.

1. There is some debate on when a political group in parliament should be referred to as a "party" rather than as a "club" or "faction" (e.g., Hoadley 1980; Sartori 1976). Some argue that the concept of "party" necessarily involves appealing to voters whereas groups that operate purely within legislatures are characterized as factions (see the discussion in Hoadley 1980). Throughout the article, we use a broad definition and use the term "party" also in the absence of such electoral bonds (see also Scarrow 2006). This follows the contemporary usage of the term (the groups in the Frankfurt Assembly called themselves "parties").

2. The main English-language publication on the FA is Eyck (1968). A general treatment of the FA in German is available in Botzenhart (1977).

3 . The closest approximation was loose groups of parliamentarians in a few southern German states and political clubs outside of parliamentary assemblies (Boldt 1971, 44-53; Kramer 1968, 16-73; Langewiesche 1978, 329).

4. Depending on the party, an issue was designated a party vote by simple (parties of the left) or qualified majority in the caucus.

5. The choice set includes all parties as well as the option of remaining unaffiliated but ignores the possibility of founding a new party. This assumption is plausible given that we analyze the party system in its most differentiated form (see the online Supporting Information for details).

6. The data set is deposited at the Central Archive for Empirical Social Research of GESIS in Cologne, Germany, with the study ID ZA8003.

7. Whenever the data set only contains the year of birth of an MP, we use January 1 as the birthday.

8. The Vorparlament met from March 31 to April 3, 1848 to prepare the opening of the Frankfurt Assembly. It consisted of 574 persons chosen from state-level parliaments.

9. Most MPs rarely or never spoke on the floor so that we cannot infer their ideology via quantitative text analysis.

10. Following standard practice, we used uninformative normal priors with mean 0 and precision 1 for the legislator's ideal points and mean 0 and precision 0.04 for the bill parameters. We ran 20,000 MCMC iterations, discarding the first 10,000 iterations as burn in, and recording every 100th posterior draw. 
11. Adding a second dimension yields an increase of less than 2 percentage points.

12. The wide spread of positions within parties also suggests that links that may have existed between MPs who had been members of the Vorparlament did not lead to highly cohesive parties. Furthermore, only $18 \%$ of the members in our analysis belonged to the Vorparlament.

13. Our analysis below indirectly confirms this argument by demonstrating that ideology alone is an insufficient predictor of party membership.

14. Similar approaches have been used, for example, by Kedar (2005) and Shikano, Herrmann, and Thurner (2009).

15. The models were estimated using the asclogit command in Stata 14; the coefficient plots were produced using the coefplot package (Jann 2013). Multicollinearity does not pose problems for the analysis as the independent variables are at most mildly related. The highest correlation is $r=0.41$ between Similarity: Political club and Similarity: Political sentence. Most correlations are well below 0.20 . The strongest correlation between ideological similarity and any other explanatory variable is $r=-0.22$.

16. We also estimated two separate coefficients for each of the other explanatory factors. Likelihood ratio tests show that the models with separate coefficients are not statistically superior $(p>0.05)$ to the models with a single coefficient for all explanatory variables except for the similarity regarding previous membership in the Vorparlament. In the case of similarity regarding Vorparlament, the two coefficients are statistically distinct, but the substantive findings are very similar. For these reasons, we present the simpler models here.

17. To assess the robustness of our findings, we also tested a slightly different classification of party memberships by Koch (1989). The results were equivalent to the ones reported above.

18. Even the prospects of the FA itself were unclear in 1848 because the success of the revolution and the design of a future parliament were uncertain. Thus, it seems unlikely that many MPs were basing their decision to join a party on the effect this might have for future re-election.

\section{REFERENCES}

Aldrich, John H. 1995. Why Parties? The Origin and Transformation of Political Parties in America. Chicago: University of Chicago Press.

Aldrich, John H., and David Rohde. 2000. "The Consequences of Party Organization in the House: The Role of the Majority and Minority Parties in Conditional Party Government." In Polarized Politics. Congress and the President in a Partisan Era, ed. Jon Bond and Richard Fleischer. Washington, DC: CQ Press, 31-72.

Armstrong, David A., Ryan Bakker, Royce Carroll, Christopher Hare, Keith T. Poole, and Howard Rosenthal. 2014. Analyzing Spatial Models of Choice and Judgment with R. Hoboken, NJ: CRC Press. 
Berchtold, Klaus. 1986. "Die politischen Parteien und ihre parlamentarischen Klubs bis 1918." In Österreichs Parlamentarismus: Werden und System, ed. Herbert Schambeck. Berlin: Duncker \& Humblot, 137-67.

Best, Heinrich. 1990. Die Männer von Bildung und Besitz. Struktur und Handeln parlamentarischer Führungsgruppen in Deutschland und Frankreich 1849/49. Düsseldorf, Ger.: Droste.

Best, Heinrich, and Wilhelm Weege. 1996. Biographisches Handbuch der Abgeordneten der Frankfurter Nationalversammlung 1848/49. Düsseldorf, Ger.: Droste.

Biedermann, Karl. 1849. Erinnerungen aus der Paulskirche. Leipzig, Ger.: Mayer.

Boldt, Werner. 1971. Die Anfänge des deutschen Parteiwesens. Fraktionen, politische Vereine und Parteien in der Revolution 1848. Paderborn, Ger.: Schöningh.

Botzenhart, Manfred. 1977. Deutscher Parlamentarismus in der Revolutionszeit 1848-50. Düsseldorf, Ger.: Droste.

Bowler, Shaun. 2000. "Parties in Legislatures. Two Competing Explanations." In Parties Without Partisans. Political Change in Advanced Industrial Democracies, ed. Russell J. Dalton, and Martin P. Wattenberg. Oxford: Oxford University Press, 157-79.

Capoccia, Giovanni, and Daniel Ziblatt. 2010. "The Historical Turn in Democratization Studies: A New Research Agenda for Europe and Beyond." Comparative Political Studies 43: 931-68.

Carroll, Royce, Gary W. Cox, and Mónica Pachón. 2006. "How Parties Create Electoral Democracy, Chapter 2.” Legislative Studies Quarterly 31: 153-74.

Clinton, Joshua D., Simon D. Jackman, and Douglas Rivers. 2004. "The Statistical Analysis of Roll Call Data: A Unified Approach.” American Political Science Review 98: 355-70.

Cox, Gary W. 1987. The Efficient Secret. The Cabinet and the Development of Political Parties in Victorian England. Cambridge: Cambridge University Press.

Cox, Gary W. 2006. "The Organization of Democratic Legislatures.” In The Oxford Handbook of Political Economy, ed. Barry Weingast and Donald Wittman. Oxford: Oxford University Press, 141-61.

Cox, Gary W., and Mathew D. McCubbins. 1993. Legislative Leviathan. Party Government in the House. Berkeley: University of California Press.

Cox, Gary W., and Mathew D. McCubbins. 2005. Setting the Agenda. Responsible Party Government in the U.S. House of Representatives. Cambridge: Cambridge University Press.

Desposato, Scott W. 2006. "Parties for Rent? Ambition, Ideology, and Party Switching in Brazil's Chamber of Deputies." American Journal of Political Science 50: 62-80.

Desposato, Scott W., and Ethan Scheiner. 2008. "Governmental Centralization and Party Affiliation. Legislator Strategies in Brazil and Japan." American Political Science Review 102: 509-24. 
Duverger, Maurice. 1972. Political Parties: Their Organization and Activity in the Modern State (3rd ed.). London: Methuen.

Eggers, Andrew C., and Arthur Spirling. 2014. "Electoral Security as a Determinant of Legislator Activity, 1832-1918: New Data and Methods for Analyzing British Political Development." Legislative Studies Quarterly 39: 593-620.

Eggers, Andrew C., and Arthur Spirling. 2016. "Party Cohesion in Westminster Systems: Inducements, Replacement and Discipline in the House of Commons, 1836-1910.” British Journal of Political Science 46: 567-89.

Eyck, Frank. 1968. The Frankfurt Parliament 1848-1849. London: Macmillan.

Godbout, Jean-Francois, and Bjørn Høyland. 2015. "Unity in Diversity? The Development of Political Parties in the Parliament of Canada, 18672011." British Journal of Political Science 47: 545-69.

Hanmer, Michael J., and Kerem O. Kalkan. 2013. "Behind the Curve. Clarifying the Best Approach to Calculating Predicted Probabilites and Marginal Effects from Limited Dependent Variable Models." American Journal of Political Science 57: 263-77.

Heller, William B., and Carol Mershon, eds. 2009. Political Parties and Legislative Party Switching. Houndmills, UK: Palgrave MacMillan.

Heller, William B., and Carol Mershon. 2008. "Dealing in Discipline. Party Switching and Legislative Voting in the Italian Chamber of Deputies, 1988-2000.” American Journal of Political Science 52: 910-25.

Herrmann, Michael, and Ulrich Sieberer. 2018. "The Basic Space of a Revolutionary Parliament: Scaling the Frankfurt Assembly of 1848/49." Party Politics. https://doi.org/10.1177/1354068817749778

Hinich, Melvin J., and Michael C. Munger. 1996. Ideology and the Theory of Political Choice. Ann Arbor: University of Michigan Press.

Hoadley, John F. 1980. "The Emergence of Political Parties in Congress, 17891803." American Political Science Review 74: 757-79.

Jackman, Simon D. 2008. pscl: Classes and Methods for $R$ Developed in the Political Science Computational Laboratory. $R$ package version 1.00. Stanford, CA: Stanford University.

Jann, Ben. 2013. "Coefplot: Stata Module to Plot Regression Coefficients and Other Results." http://ideas.repec.org/c/boc/bocode/s457686.html

Katz, Richard S., and Peter Mair. 1995. "Changing Models of Party Organization and Party Democracy. The Emergence of the Cartel Party." Party Politics 1: 5-28.

Kedar, Orit. 2005. "How Diffusion of Power in Parliaments Affects Voter Choice." Political Analysis 13: 410-29.

Koch, Rainer, ed. 1989. Die Frankfurter Nationalversammlung 1848/49. Ein Handlexikon der Abgeordneten der deutschen verfassungsgebenden Reichs-Versammlung. Kelkheim, Ger: H. Kunz Verlag.

Kramer, Helmut. 1968. Fraktionsbindungen in den deutschen Volksvertretungen 1819-1849. Berlin: Duncker \& Humblot.

Krouwel, André. 2006. "Party Models." In Handbook of Party Politics, ed. Richard S. Katz and William Crotty. London: Sage, 249-69. 
Langewiesche, Dieter. 1978. "Die Anfänge der deutschen Parteien. Partei, Fraktion und Verein in der Revolution von 1848/49." Geschichte und Gesellschaft 4: 324-61.

Laver, Michael, and Kenneth Benoit. 2003. "The Evolution of Party Systems Between Elections." American Journal of Political Science 47: 215-33.

Long, J. Scott, and Jeremy Freese. 2006. Regression Models for Categorical Dependent Variables Using Stata (2nd ed.). College Station, TX: Stata Press.

Mattheisen, Donald J. 1981. "German Parliamentarism in 1848: Roll-Call Voting in the Frankfurt Assembly." Social Science History 5: 469-82.

McElroy, Gail. 2009. "Intra-Party Politics at the Trans-National Level. Party Switching in the European Parliament." In Intra-Party Politics and Coalition Government in Parliamentary Democracies, ed. Daniela Gianetti and Kenneth Benoit. London: Routledge, 205-25.

McFadden, Daniel. 1974. "Conditional Logit Analysis of Qualitative Choice Behavior." In Frontiers in Econometrics, ed. Paul Zarembka. New York: Academic Press, 105-42.

Meng, Xiao-Li, and Donald B Rubin. 1992. "Performing Likelihood Ratio Tests with Multiply-Imputed Data Sets." Biometrika 79: 103-11.

Mershon, Carol. 2014. "Legislative Party Switching." In The Oxford Handbook of Legislative Studies, ed. Shane Martin, Thomas Saalfeld, and Kaare W. Strøm. Oxford: Oxford University Press, 418-35.

Mershon, Carol, and Olga Shvetsova. 2013. "The Microfoundations of Party System Stability in Legislatures.” Journal of Politics 75: 865-78.

Poole, Keith T. 2005. Spatial Models of Parliamentary Voting. New York: Cambridge University Press.

Riker, William H. 1982. Liberalism Against Populism. A Confrontation Between the Theory of Democracy and the Theory of Social Choice. San Francisco, CA: Freeman.

Riker, William H. 1986. The Art of Political Manipulation. New Haven, CT: Yale University Press.

Rubin, Donald B. 1987. Multiple Imputation for Nonresponse in Surveys. New York: Wiley.

Saalfeld, Thomas, and Kaare W. Strøm. 2014. "Political Parties and Legislators." In The Oxford Handbook of Legislative Studies, ed. Shane Martin, Thomas Saalfeld, and Kaare W. Strøm. Oxford: Oxford University Press, 371-98.

Sartori, Giovanni. 1976. Parties and Party Systems. A Framework for Analysis. Cambridge: Cambridge University Press.

Scarrow, Susan E. 2006. "The Nineteenth-Century Origins of Modern Political Parties: The Unwanted Emergence of Party-Based Politics.” In Handbook of Party Politics, ed. Richard S. Katz and William Crotty. London: Sage, $16-24$.

Schwartz, Thomas. 2018. Cycles and Social Choice: The True and Unabridged Story of a Most Protean Paradox. Cambridge: Cambridge University Press. 
Shikano, Susumu, Michael Herrmann, and Paul W. Thurner. 2009. "Strategic Voting Under Proportional Representation: Threshold Insurance in German Elections.” West European Politics 32: 634-56.

Sieberer, Ulrich. 2013. "Elections in Western European Parliaments." European Journal of Political Research 52: 512-35.

Sieberer, Ulrich, and Michael Herrmann. 2017. "Forgotten Parliamentarization in Nineteenth Century Germany. Parliamentary Government in the Frankfurt Assembly of 1848/49." Working paper. Universities of Bamberg and Konstanz.

Thames, Frank C. 2007. "Searching for the Electoral Connection. Parliamentary Party Switching in the Ukrainian Rada, 1988-2002." Legislative Studies Quarterly 32: 223-56.

Weingast, Barry R. 1998. "Political Stability and Civil War: Institutions, Commitment, and American Democracy." In Analytic Narratives, ed. Robert H. Bates, Avner Greif, Margaret Levi, Jean-Laurent Rosenthal, and Barry R. Weingast. Princeton, NJ: Princeton University Press, 148-93.

Weyland, Kurt. 2016. "Crafting Counterrevolution: How Reactionaries Learned to Combat Change in 1848." American Political Science Review 110: 215-31.

Willumsen, David M. 2017. The Acceptance of Party Unity in Parliamentary Democracies. Oxford: Oxford University Press.

Ziblatt, Daniel. 2017. Conservative Parties and the Birth of Democracy. Cambridge: Cambridge University Press.

Ziebura, Gilbert. 1963. "Anfänge des deutschen Parlamentarismus. Geschäftsverfahren und Entscheidungsprozeß in der ersten deutschen Nationalversammlung 1848/49." In Faktoren der politischen Entscheidung, ed. Gerhard Ritter and Gilbert Ziebura Berlin: De Gruyter, 185-236.

Statistical Results

Table SI-1. Descriptive Statistics of the Variables in the Model (Estimation Sample of 506 MPs)

Table SI-2. Estimation Results of the Models Reported in Figure 2 The Logic of Our Similarity Measures and Further Information on the Best Data

Substantive Interpretation of the Ideological Conflict Dimension Extracted from Early Roll-Call Votes

Figure SI-1. Response Function of the Estimated Ideal Points

Details on the Statistical Model Used 